localities from which the larvæ were obtained for specimens of Alysia manducator have been observed in quantity near carrion in several districts in North Wales. On the other hand, it is well known that the primary attraction of this parasite is the chemotropic action of carrion, hence it would appear that a live sheep attacked by larvæ of Lucilia sericata offers no attraction for ovipositing females of Alysia manducator, and thus the larva in this environment escape the attacks of the parasite.

University College of North Wales,

W. Maldowyn Davies. Bangor.

\section{Coloured Glass as a Deterrent to House Flies.}

LAST autumn we received an inquiry from Mr. L. Macqueen Douglas, of Newpark, Mid Calder, Midlothian, who asked us whether we had any data concerning the action of coloured glass on house flies. In his experience coloured class, especially blue, acted as a deterrent, and he was using it in the construction of abattoirs, etc. At that time we were unable to obtain any further information upon the subject. On the appearance in NATURE of April 5 of the letter from Messrs. Pilkington Bros., who stated that red and yellow are the best deterrents and that blue and green are not nearly so effective, $\mathrm{I}$ communicated these facts to Mr. Douglas. He replied stating that he had carried his experiments somewhat further, and that from his experience blue glass is to be preferred to yellow for two reasons. First, he found that the blue glass was completely effective in preventing the development of flies; and secondly, that the blue glass does not give an offensive look to the meat, while yellow glass gives it an unhealthy-looking colour which from a commercial point of view is highly objectionable.

I might add that Mr. Douglas's experience of abattoirs and their construction is very extensive.

King's Buildings,

West Mains Road,

University of Edinburgh, May 1.

Messrs. Pilkington Bros., in Nature of April 5, raise an interesting point regarding house flies and their dislike of light of certain hues. The following observations, made during September of last year, may be of interest.

Two similar small rooms were roof-glazed, one with ordinary rolled-plate, the other with a proprietary heat-absorbing glass transmitting bluish-green light. Ventilators in the two rooms gave insects equal opportunities for ingress, but at the end of a fortnight the numbers of insects in the rooms were so obviously unequal that a count was made, with the following result :

\begin{tabular}{|lcc|c|c|c|}
\hline \multicolumn{2}{|r|}{ Type of Insect. } & & Under Clear Glass. & $\begin{array}{c}\text { Under Bluish- } \\
\text { Green Glass. }\end{array}$ \\
\hline Flies & $\cdot$ & $\cdot$ & $\cdot$ & 19 & 8 \\
Moths : & $\cdot$ & $\cdot$ & $:$ & 4 & 1 \\
Wasps . & $\cdot$ & $\cdot$ & $\cdot$ & 4 & 0 \\
Spiders. & $\cdot$ & $\cdot$ & $\cdot$ & 3 & 0 \\
\hline
\end{tabular}

It should be added that, during hot weather, the maximum air temperature in the room glazed with rolled-plate was usually $5^{\circ}$ or $6^{\circ} \mathrm{F}$. greater than that in the other room. There was also a marked deficiency of infra-red radiation beneath the bluish-green glass which may partly account for the results obtained.

H. E. BecketT.

\section{Nutritive Value of Elm Tree Bark.}

IN the water-meadows opposite my home in Chalfont St. Peter several elm trees were blown down by last winter's gales. The horses and cows grazing on these meadows spent much of their time in chewing off the bark of the boughs of the fallen trees, although there was abundant young grass growing on the meadows all through the last months of a mild winter.

Interested by this fact, I put two lots of seven mice, just weaned from well-fed, healthy mothers of known stock, on a diet of white bread and water, and to one lot $\mathbf{I}$ gave some elm tree twigs every few days. The mice gnawed the bark off the twigs. At the end of seven weeks these mice had gained $45 \mathrm{gm}$., while the control lot had gained only $22 \mathrm{gm}$. in weight. X-ray photographs showed no difference in the lines of ossification of the bones in the two lots, so that the bark was not eaten for the sake of vitamin D. This might be thought to be deficient in winter grass owing to the low intensity of the short ultraviolet rays of the sun. The fur of the mice which ate the bark had a sleaker appearance.

\section{LEONARD HILt.}

\section{Ionisation in Nitrogen.}

Experiments on corona discharge in carefully purified nitrogen at low pressures show that the mobility of the negative carriers is much lower than that found for electrons by Townsend and Bailey (Phil. Mag., December 1921), as is shown by the following table :

$$
\begin{array}{ccc}
X / p & \omega p & \\
\text { From } 10 \text { to } 40 & 4.4 \times 10^{5} & \text { Townsend and Bailey } \\
25 & 12.9 \times 10^{3} & \text { Corona Experiments } \\
20 & 9 \cdot 0 \times 10^{3} & 5.7 \times 10^{3}
\end{array}
$$

Since Townsend and Bailey's experiments show that electrons retain their high mobility for a considerable time, the carriers cannot all be electronic. The greatest possible proportion of electrons present varies approximately linearly from 0.025 when $X_{0} / p$ (at the surface of the inner cylinder) is 350 to 0.012 when $X_{0} / p$ is 200 .

Electrical Laboratory,

Oxford, April 23.

\section{Undercurrents in the Strait of Gibraltar.}

IN view of the lively discussion of the undercurrents in the Strait of Gibraltar during recent years, some observations made by H.M. Surveying Ship Goldfinch (Lieut.-Commander F. H. Walter) in 1905 with the Pilsbury Current Meter, where I was serving as Senior Assistant Surveyor, may be of interest. They were not published, since they were not taken under good conditions, but they are amply sufficient to show that at a position N. $53^{\circ} \mathrm{W}$. (True), 7 miles from Cape Spartel, the current between the surface and 200 fathoms was easterly and weak; below 200 fathoms it began to turn to the west, and observations between 250 and 290 fathoms showed currents of more than 5 knots flowing nearly west True. It is hoped that it.will be possible to publish the observations in full, shortly.

H. P. Douglas

(Rear-Admiral, and

Hydrographic Department, Hydrographer of the Navy). Admiralty, London, S.W.1, April 17.

No. 3160 , VoL. 125] 